\title{
PEMETAAN DAN STRATEGI PEMBERDAYAAN PENGENTASAN KEMISKINAN PADA JEMAAT - JEMAAT GEREJA MASEHI INJILI DI HALMAHERA (GMIH) DI KABUPATEN PULAU MOROTAI
}

\author{
(Versi Ringkas Laporan Penelitian Hibah Bersaing Tahun 2015. Versi Lengkap Laporan ini \\ Tersimpan pada LPPM Universitas Halmahera - Tobelo)
}

Oleh:

Arkipus Djurubasa

Ricardo Freedom Nanuru

e-mail: ricardonanuru632@gmail.com

\begin{abstract}
RINGKASAN
Penelitian ini bertolak dari kegelisahan terhadap begitu banyaknya jemaat-jemaat Gereja Masehi Injili di Halmahera (GMIH), khususnya yang berada di kepulauan atau yang terpisah dari pulau besar Halmahera, yang berada pada tataran ekonomi lemah atau masuk pada Kategori C bila mengikuti klasifikasi Sinode GMIH. Penelitian ini bertujuan untuk menggambarkan detil masalah kemiskinan di jemaat-jemaat GMIH yang berada di Kabupaten Pulau Morotai menurut jemaat atau masyarakat miskin itu sendiri, kemudian didesain suatu metode penanggulangan kemiskinan sesuai dengan permasalahan yang dihadapi jemaat atau masyarakat miskin. Target khusus yang ingin dicapai penelitian ini adalah memetakan lokasi kemiskinan dan menciptakan strategi pemberdayaan pengentasan kemiskinan. Demi mencapai target khusus itu, maka penelitian ini berupaya menguraikan faktor-faktor determinan yang berpengaruh terhadap perilaku jemaat miskin dengan mendesain model pemberdayaan yang efektif dalam mengeluarkan dan meningkatkan kesejahteraan jemaat atau masyarakat miskin tersebut. Metode yang digunakan adalah metode kualitatif dengan teknik pengumpulan data observasi, wawancara mendalam, dan focus group disscusion (FGD). Data dianalisis dengan menggunakan pendekatan emik yang merupakan derivasi dari paradigma penelitian fenomenologi, naturalistik, yang berusaha mengungkap fenomena berdasarkan apa yang diketahui, dipercaya, dirasakan, dan dilakoni oleh jemaat atau masyarakat yang menjadi objek penelitian. Berdasarkan hasil penelitian, maka dapat disimpulkan bahwa konsep kemiskinan yang muncul cenderung sangat subjektif yang mengindikasikan bahwa masyarakat/jemaat tidak merasa miskin seperti yang diliteraturkan oleh pemerintah dalam hal ini BPS. Hal ini sangat dipengaruhi oleh berbagai latar belakang yang berkembang dalam kehhidupan subjektif masyarakat/jemaat miskin di Morotai Selatan. Secara subjektif, perilaku masyarakat/jemaat miskin di lokasi penelitian dipengaruhi oleh faktor internal (pemahaman teologis jemaat dan tingkat pendidikan), dan faktor eksternal yaitu (dampak konflik sosial tahun 1999 dan pemerataan bantuan pemerintah serta ketersediaan sumber daya alam).
\end{abstract}




\section{Bab I Pendahuluan}

Mengawali latar belakang dan permasalahan yang dikemukakan di sini, hendak ditegaskan bahwa masalah kemiskinan dan dampak yang ditimbulkannya adalah juga merupakan pokok bahasan ilmu teologi atau ilmu agama, apapun agamanya, dan bukan hanya menjadi bagian dari ilmu-ilmu sosial yang lain. Untuk itu sebagai para teolog dan pemerhati kemiskinan, meneliti dan membahas masalah kemiskinan adalah bagian dari tanggungjawab moral dan iman kepada masyarakat sekaligus kepada Tuhan yang memberikan hidup ini.

Hidup di Indonesia bila dibayangkan tentu sangat menyenangkan. Alamnya ramah, hasil buminya melimpah, sumber daya alam yang dipakai untuk menunjang proses kehidupan terdeteksi di mana-mana. Namun apakah benar keadaan menyenangkan itu terjadi di Indonesia? Beragam pandangan atau pendapat tentu dilontarkan untuk menjawab pertanyaan ini. Ada yang menjawab menyenangkan, namun ada begitu banyak orang juga yang menjawab sebaliknya (Nanuru, 2011). Orang-orang yang menjawab menyenangkan terhadap pertanyaan di atas biasanya hidup dalam kemewahan, hidup dalam kemapanan, sedangkan yang menjawab sebaliknya biasanya hidup dalam suasana yang biasa disebut kemiskinan. Kemiskinan biasanya dibahasakan sebagai masalah dalam dunia ekonomi, dimana orang miskin adalah orang-orang yang memiliki tingkat ekonomi rendah, "hidup susah". Baik dalam hal pemenuhan kebutuhan sandang, pangan dan papan, maupun kebutuhan memperoleh akses kepada pendidikan, kesehatan, dan lain sebagainya.

Kemiskinan merupakan salah satu masalah serius dalam proses pembangunan nasional di Indonesia. Masalah ini seolah-olah tidak dapat dituntaskan secara serius, padahal upaya pemerintah telah memperkenalkan berbagai paket dan program yang melibatkan sejumlah pakar kemiskinan nasional dan internasional. Hakekatnya belum ada keberlanjutan (sustainability) sistem penanganan kemiskinan baik dalam satu rezim kekuasaan maupun pada saat peralihan rezim (Pattinama, 2009).

Setiap harinya diberitakan lewat media, baik cetak maupun elektronik tentang kesenjangan dan pergesekkan dalam masyarakat yang diakibatkan oleh masalah kemiskinan. Salah satu hal menarik yang terjadi belakangan ini adalah seputar eksploitasi atau dapat dikatakan "perbudakan" buruh yang dilakukan oleh pengusaha. Masalah-masalah ini memerlukan penanggulangan cepat serta tepat sasaran, yang nantinya berdampak pada berkurangnya gesekan dalam masyarakat tersebut. Berdasarkan hal-hal di atas, dapat 
dinyatakan bahwa kemiskinan merupakan suatu realitas yang tidak dapat dibantah lagi di tengah-tengah kehidupan masyarakat Indonesia, termasuk di Maluku Utara.

Upaya-upaya pengentasan kemiskinan, baik yang dikarenakan ketidakberuntungan situasi (deprivation trap) atau bisa juga miskin akibat dimiskinkan atau yang kita kenal sebagai kemiskinan struktural, pada hakikatnya sudah dilakukan sejak lama. Deretan program pengentasan kemiskinan telah banyak diluncurkan oleh pemerintah, mulai dari Inpres Desa Tertinggal (IDT), Program Tabungan Kesejahteraan Rakyat Kredit Usaha untuk Kesejahteraan Rakyat (Takesra-Kukesra), Program Penanggulangan Dampak Krisis Ekonomi (PDM-DKE), dan Program Jaring Pengaman Sosial Bidang Kesehatan (JPS-BK). Kemudian juga diteruskan dengan bergulirnya Program Subsidi Langsung Tunai/Bantuan Langsung Tunai (SLT/BLT) dan Bantuan Operasional Sekolah (BOS). Terakhir, program penanggulangan kemiskinan yang diluncurkan pemerintah berupa Program Bantuan Siswa Miskin (BSM), Program Keluarga Harapan (PKH). Kesemua program tersebut memiliki satu tujuan utama yaitu berupaya untuk mengentaskan masyarakat dari kemiskinan dalam suatu rangkaian program pemberdayaan. Bila dicermati, terdapat beberapa kelemahan mendasar dari berbagai program pengentasan kemiskinan selama ini. Pertama, tidak optimalnya mekanisme pemberdayaan warga miskin. Hal ini terjadi karena program lebih bersifat dan berorientasi pada 'belas kasihan' sehingga dana bantuan lebih dimaknai sebagai “dana bantuan cuma-cuma" dari pemerintah. Kedua, asumsi yang dibangun lebih menekankan bahwa warga miskin membutuhkan modal. Konsep ini dianggap menghilangkan kendala sikap mental dan kultural yang dimiliki oleh warga miskin. Muaranya adalah rendahnya tingkat perubahan terhadap cara pandang, sikap, dan perilaku warga miskin dan warga masyarakat lainnya dalam memahami akar kemiskinan. Ketiga, program pemberdayaan lebih dimaknai secara parsial, misalnya titik berat kegiatan program hanya mengintervensi pada satu aspek saja, seperti aspek ekonomi atau aspek fisik, belum diintegrasikan dalam suatu program pemberdayaan yang terpadu (Taufiq, et. al, 2010).

Berdasarkan pada upaya-upaya yang dilakukan pemerintah dan pendapat-pendapat mengenainya, maka dapat disimpulkan bahwa upaya-upaya penanggulangan kemiskinan yang telah dilakukan belum efektif, sehingga sampai saat ini belum membuahkan hasil yang memuaskan. Hal ini dapat dilihat pada data-data masyarakat miskin yang dikeluarkan oleh pemerintah dalam hal ini Badan Pusat Statistik (BPS) termasuk BPS Maluku Utara yang sampai September 2012 tidak mengalami penurunan signifikan. Ketidakberhasilan penurunan jumlah masyarakat miskin ini yang dilakukan pemerintah ini bersumber dari cara pemahaman 
dan penanggulangan kemiskinan yang diartikan sebagai kondisi ekonomi semata, padahal ada sisi lain selain faktor ekonomi, misalnya budaya dan pandangan hidup masyarakat, termasuk didalamnya pandangan agama/kepercayaan terhadap kemiskinan. Pandangan teologis agama, diindikasikan dapat juga menyumbang bagi pandangan penganutnya terhadap kemiskinan.

Gereja Masehi Injili di Halmahera (selanjutnya disingkat GMIH) merupakan bagian yang tak terpisahkan dari masyarakat Maluku Utara secara umum.Secara khusus, jemaatjemaat GMIH yang merupakan mayoritas penduduk atau masyarakat Kristen di Maluku Utara menyumbang angka kemiskinan yang signifikan bagi persoalan kemiskinan di Maluku Utara. Hal ini terlihat dari fakta bahwa 75 persen jemaat GMIH berada pada kategori C, yaitu jemaat yang berada pada tingkat ekonomi dan finansial yang lemah. Hal ini merupakan masalah tersendiri bagi GMIH dalam usaha membantu pemerintah dalam mengentaskan kemiskinan di Maluku Utara.

\section{Bab II Tinjauan Pustaka}

\section{A. KonsepKemiskinan}

Pengertian kemiskinan sangat beragam, mulai dari sekedar ketidakmampuan memenuhi kebutuhan komsumsi dasar dan memperbaiki keadaan hidup hingga pengertian yang lebih luas yang melibatkan komponen-komponen sosial dan moral. Pengertian atau defenisi orang miskin yang hanya dilihat dari sudut pemenuhan kebutuhan konsumsi saja sudah tidak cukup, karena: (1) pengertian ini sering tidak berhubungan dengan defenisi yang dimaksud oleh orang miskin itu sendiri, dan tidak cukup untuk memahami realitas kemiskinan; (2) pengertian tersebut dapat menjerumuskan kepada kesimpulan yang salah, bahwa menanggulangi kemiskinan cukup hanya dengan menyediakan bahan makanan yang memadai, dan (3) pengertian tersebut telah terbukti tidak bermanfaat bagi pengambil keputusan ketika merumuskan kebijakan lintas sektoral dan bisa kontra produktif (Smeru, 2003).

Sejalan dengan pengertian yang dikemukakan di atas, World Bank (Bank Dunia) memandang kemiskinan sebagai deprivasi dalam kesejahteraan. Berdasarkan defenisi tersebut kemiskinan dapat dipandang dari beberapa sisi. Dari pandangan konvensional kemiskinan dipandang dari sisi moneter, dimana kemiskinan diukur dengan membandingkan pendapatan/konsumsi individu dengan beberapa batasan tertentu, jika mereka berada di 
bawah batasan tersebut, maka mereka dianggap miskin. Pandangan mengenai kemiskinan berikutnya adalah bahwa kemiskinan tidak hanya sebatas ukuran moneter, tetapi juga mencakup miskin nutrisi yang diukur dengan memeriksa apakah pertumbuhan anak-anak terhambat. Selain itu, juga bisa dari miskin pendidikan, misalnya dengan menggunakan indikator angka buta huruf. Selanjutnya pandangan yang lebih luas mengenai kemiskinan adalah kemiskinan ada jika masyarakat kekurangan kemampuan dasar, sehingga pendapatan dan pendidikan yang dimiliki tidak memadai atau kesehatan yang buruk, atau ketidakamanan, atau kepercayaan diri yang rendah, atau rasa ketidakberdayaan, atau tidak adanya hak bebas berpendapat. Berdasarkan pandangan ini, kemiskinan adalah fenomena multi dimensi, dan solusi untuk mengatasinya tidaklah sederhana (BPPKS, 2012).

Selain pengertian-pengertian di atas, KIKIS dalam Umanah, dkk. (2012) mendefenisikan pengertian kemiskinan sebagai kondisi dimana tidak terpenuhinya kebutuhan asasi yang meliputi: subsistensi, afeksi, keamanan, identitas, proteksi, kreasi kebebasan, partisipasi, dan waktu luang. Kemiskinan subsistensi terjadi karena rendahnya pendapatan, tak terpenuhinya akan sandang, pangan dan papan, serta kebutuhan-kebutuhan dasar lainnya. Kemiskinan perlindungan terjadi karena meluasnya budaya kekerasan atau tidak memadainya sistem perlindungan atas hak dan kebutuhan dasar. Kemiskinan afeksi terjadi karena adanya bentuk-bentuk penindasan, pola hubungan eksploitatif antara manusia dengan manusia, dan antar manusia dengan alam. Kemiskinan pemahaman terjadi karena kualitas pendidikan yang rendah, selain faktor kuantitas yang tidak mampu memenuhi kebutuhan. Kemiskinan partisipasi terjadi karena adanya diskriminasi dan peminggiran rakyat dari proses pengambilan keputusan, sedangkan kemiskinan identitas terjadi karena dipaksakannya nilainilai asing terhadap budaya lokal yang mengakibatkan hancurnya nilai-nilai sosio-kultural yang ada.

KIKIS dalam Umanah, dkk. (2012) lebih jauh mengemukakan hasil penelitian tentang masyarakat miskin menurut tipologi, yaitu: (1) menurut masyarakat "miskin perkotaan", kemiskinan adalah suatu keadaan dimana orang tidak mempunyai harta benda, pendidikan dan tidak mempunyai hubungan secara leluasa dengan pihan-pihak tertentu, seperti: bank, pejabat, pengusaha, dan sebagainya; (2) masyarakat "miskin pegunungan" mendefenisikan kemiskinan dalam beberapa cakupan bidang kehidupan, antara lain kehidupan politik dan hukum, ekonomi, sosial budaya dan gender. 
Kemiskinan dalam bidang politik dan hukum, antara lain: (1) adanya rasa takut dalam mengekspresikan kepentingan masyarakat lokal; (2) tertutupnya akses informasi; (3) hilang dan ditutupnya akses masyarakat terhadap hutan; (4) masyarakat menjadi penonton kekayaan alam di daerahnya; (5) tertutupnya akses dalam proses pengambilan keputusan; (6) perampasan hak individu dan kolektif; (7) tidak berdaulat terhadap pengelolaan sumber daya yang ada; (8) pengabaian pengetahuan lokal; (9) kesadaran akan hak terhadap hutan dan sumber daya alam; (10) perampasan hak akses pada sumber daya hutan atau agraria; (11) pengabaian hukum adat dan institusi adat, dan (12) hilangnya sumber-sumber pemenuhan kebutuhan pokok.

Kemiskinan di bidang ekonomi, antara lain: (1) kehilangan mata pencaharian; (2) tidak bisa memenuhi kebutuhan pokok, sandang, pangan, papan, kesehatan, pendidikan, dan kebudayaan; (3) kemiskinan SDA sebagai modal kehidupan; (4) tidak dapat makan sampai kenyang, tidak dapat menyekolahkan anak, diposisikan tidak manusiawi; (5) tidak memiliki lahan untuk bertani, kebutuhan-kebutuhan keluarga tidak tercukupi oleh hasil hutan yang dibatasi; (6) hilangnya sumber penghidupan masyarakat lokal; (7) kebutuhan dasar dalam hidup tidak sesuai dengan situasi aktual di lokasi, dan (8) sumber daya air yang ada di hutan dirusak oleh perhutani.

Kemiskinan dalam bidang sosial budaya dan gender, antara lain: (1) menurunnya rasa solidaritas, persaudaraan, rasa senasib sepenanggungan dengan sesama; (2) pelemahan institusi adat dengan pembentukan dewan adat oleh pemerintah; (3) pelecehan terhadap hukum dan institusi adat; (4) menurunnya rasa kebersamaan dan penghargaan; (5) kemampuan adaptasi institusi lokal terhadap perubahan yang terjadi; (6) resistensi kelembagaan lokal lemah; (7) penghancuran tempat-tempat keramat; (8) keharusan mengganti mata pencaharian; (9) kehilangan hutan rimba; (10) kemiskinan dari dimensi keadilan gender; (11) kelompok tani hutan selalu beranggotakan laki-laki; (12) hancurnya hutan mengakibatkan bahan baku untuk menenun yang dilakukan perempuan menjadi musnah; (13) masuknya HPH dan perkebunan besar di teritori orang rimba menyebabkan langkahnya bahan-bahan ramuan dan untuk persalinan; dan (14) mengumpulkan ranting kayu yang merupakan pekerjaan perempuan menjadi lebih sulit karena tidak diakomodasi oleh perhutani.

Setelah meninjau pengertian kemiskinan menurut hasil penelitian KIKIS yang dikutip Umanah, dkk. di atas, perlulah dikemukakan pengertian kemiskinan menurut pemerintah 
yang dalam hal ini diwakili oleh BPS (Pendataan Sosial Ekonomi Penduduk 2005 \{PSE05\}) yang mengemukakan 14 kriteria atau variabel rumah tangga miskin, yaitu: (1) luasnya lantai bangunan tempat tinggal yang dimanfaatkan untuk aktivitas sehari-hari; (2) jenis lantai bangunan tempat tinggal terluas terdiri dari tanah/bambu/kayu berkualitas rendah; (3) jenis dinding bangunan tempat tinggal terluas terdiri dari bambu/kayu berkualitas rendah; (4) fasilitas tempat buang air besar (jamban/kakus) digunakan secara bersama-sama atau menggunakan secara umum; (5) sumber air minum adalah mata air yang tidak terlindung/sungai/air hujan; (6) sumber penerangan utama bukan listrik; (7) jenis bahan bakar untuk memasak sehari-hari dari kayu/arang/minyak tanah; (8) jarang membeli daging/ayam/susu setiap minggunya; (9) anggota rumah tangga hanya mampu menyediakan makan dua kali dalam sehari; (10) tidak mampu membeli pakaian baru minimal satu stel setiap tahun; (11) bila jatuh sakit tidak berobat karena tidak ada biaya untuk berobat; (12) pekerjaan utama kepala keluarga sebagai buruh kasar dan atau tidak bekerja; (13) pendidikan tertinggi yang ditamatkan kepala keluarga SD ke bawah, dan (14) ada tidaknya barang dalam keluarga yang dapat dijual dengan nilai Rp. 500.000,- (BPS, 2005; BPPKS, 2012).

Selain PSE05, BPS pada tahun 2007 kembali mengumpulkan data kemiskinan mikro yang dikenal dengan nama SPDKP 2007. Dalam laporan SPDKP07 disebutkan beberapa kriteria umum Rumah Tangga Sangat Miskin (RTSM) seperti dibahasakan BPPKS (2012), yaitu:

1) Sebagian besar pengeluarannya digunakan untuk memenuhi konsumsi makanan pokok yang sangat sederhana,

2) Biasanya tidak mampu atau mengalami kesulitan untuk berobat ke tenaga medis, kecuali Puskesmas atau yang disubsidi pemerintah,

3) Tidak mampu membeli pakaian satu kali dalam satu tahun untuk setiap anggota rumah tangga,

4) Biasanya tidak/hanya mampu menyekolahkan anaknya sampai jenjang pendidikan SLTP.

Dari sisi kondisi fisik serta fasilitas tempat tinggal RTSM biasanya tinggal pada rumah yang:

1) Dinding rumahnya terbuat dari bambu/kayu/tembok dengan kondisi tidak baik/kualitas rendah, termasuk tembok yang sudah usang/berlumut atau tembok yang tidak diplester, 
2) Sebagian besar lantai rumah terbuat dari tanah atau kayu/semen/keramik dengan kondisi tidak baik/kualitas rendah,

3) Atap terbuat dari ijuk/rumbia atau genteng/seng/asbes dengan kondisi tidak baik/kualitas rendah,

4) Penerangan bangunan tempat tinggal bukan dari listrik atau listrik tanpa meteran,

5) Luas lantai rumah kecil (biasanya kurang dari $8 \mathrm{~m}^{2} / \mathrm{orang}$ ),

6) Sumber air minum berasal dari sumur atau mata air tak terlindung/air sungai/air hujan/lainnya.

Dari pengertian kemiskinan menurut BPS di atas, terlihat bahwa BPS menggunakan konsep kemampuan memenuhi kebutuhan dasar (basic needs approach). Dengan pendekatan ini, kemiskinan dipandang sebagai ketidakmampuan dari sisi ekonomi untuk memenuhi kebutuhan dasar makanan dan non makanan yang diukur dari sisi pengeluaran. Berdasarkan pendapat-pendapat di atas, maka yang dipakai sebagai acuan dalam penelitian ini adalah kombinasi antara pengertian kemiskinan secara subjektif dari rumah tangga miskin, dan pandangan objektif tentang rumah tangga miskin dari BPS.

\section{B. Jenis - Jenis Kemiskinan}

Kemiskinan menurut sifat dasarnya dapat dibagi ke dalam dua bagian, yaitu: (1) kemiskinan sementara (transient poverty) yaitu kemiskinan yang terjadi akibat krisis ekonomi, dan (2) kemiskinan kronik (chronic poverty) (Seldayo, et.al, 2003).

KIKIS dalam Umanah, dkk. (2012) mengemukakan jenis-jenis kemiskinan adalah: kemiskinan manusia, kemiskinan pendapatan, kemiskinan absolut, kemiskinan relatif, indeks pembangunan manusia, indeks kemiskinan manusia, dan ukuran pemberdayaan gender. Halhal yang disebutkan di atas dapat ditabelkan sebagai berikut.

Tabel Jenis dan Makna Kemiskinan

\begin{tabular}{|l|l|}
\hline \multicolumn{1}{|c|}{ Jenis Kemiskinan } & \multicolumn{1}{c|}{ Makna Kemiskinan } \\
\hline Kemiskinan manusia & $\begin{array}{l}\text { Kekurangan kapabilitas esensial manusia, terutama melek huruf } \\
\text { dan gizi. }\end{array}$ \\
\hline $\begin{array}{l}\text { Kemiskinan } \\
\text { pendapatan }\end{array}$ & $\begin{array}{l}\text { Kekurangan pendapatan sehingga tidak cukup untuk memenuhi } \\
\text { kebutuhan konsumsi minimum. }\end{array}$ \\
\hline Kemiskinan Absolut & $\begin{array}{l}\text { Tingkat kebutuhan di bawah kebutuhan minimum untuk bertahan } \\
\text { hidup yang tidak dapat dipenuhi. Diterapkan dengan mengukur } \\
\text { kebutuhan kalori minimum plus komponen bahan makanan yang } \\
\text { esensial. }\end{array}$ \\
\hline
\end{tabular}




\begin{tabular}{|l|l|}
\hline Kemiskinan relatif & $\begin{array}{l}\text { Didefenisikan dalam hubungannya dengan sesuatu rasio garis } \\
\text { kemiskinan absolut, atau di negara maju sebagai proporsi } \\
\text { pendapatan rata-rata per kapita. }\end{array}$ \\
\hline $\begin{array}{l}\text { Indeks pembangunan } \\
\text { manusia (HDI) }\end{array}$ & $\begin{array}{l}\text { Menurut program pembangunan PBB (UNDP), HDI merupakan } \\
\text { komposit dari tiga faktor: (1) harapan hidup pada waktu lahir, (2) } \\
\text { melek huruf dewasa, dan (3) pendapatan per kapita. }\end{array}$ \\
\hline $\begin{array}{l}\text { Indeks kemiskinan } \\
\text { manusia }\end{array}$ & $\begin{array}{l}\text { Ukuran UNDP untuk ketiadaan kebutuhan dasar manusia. } \\
\text { Variabel yang digunakan untuk mengukur indeks ini adalah: (1) } \\
\text { persentase orang yang diperkirakan akan meninggal sebelum usia } \\
40 \text { tahun; (2) persentase orang dewasa yang buta huruf; dan (3) } \\
\text { layanan ekonomi menyeluruh diukur dari persentase orang yang } \\
\text { tidak mempunyai akses pada layanan kesehatan dan air bersih } \\
\text { yang aman dan persentase anak-anak balita yang beratnya di } \\
\text { bawah normal. }\end{array}$ \\
\hline $\begin{array}{l}\text { Ukuran } \\
\text { pemberdayaan } \\
\text { gender }\end{array}$ & $\begin{array}{l}\text { Asesmen UNDP tentang tingkat kesenjangan gender di bidang- } \\
\text { bidang ekonomi yang penting, partisipasi politik, dan } \\
\text { pengambilan keputusan. }\end{array}$ \\
\hline
\end{tabular}

Sumber: KIKIS dalam Umanah, dkk. (2012)

\section{Bab III Tujuan dan Manfaat Penelitian}

A. Tujuan Penelitian

Adapun tujuan penelitian tahun pertama ini adalah sebagai berikut:

1. Menggambarkan secara detail penyebab kemiskinan menurut jemaat/masyarakat miskin;

2. Menjelaskan faktor-faktor yang mempengaruhi perilaku rumah tangga miskin;

3. Merumuskan strategi utama dalam penanggulangan kemiskinan yang efektif berdasarkan penyebab kemiskinan.

B. Manfaat Penelitian

Adapun manfaat penelitian ini adalah sebagai berikut:

1. Bagi Gereja Masehi Injili di Halmahera $(\mathrm{GMIH})$ penelitian ini bermanfaat sebagai bahan kajian dalam mempersiapkan program-program pemberdayaan jemaat yang berbasis langsung pada pemahaman jemaat itu sendiri.

2. Bagi Pemerintah Daerah Kabupaten Pulau Morotai, penelitian ini bermanfaat sebagai masukan dalam pengembangan program pemberdayaan masyarakat miskin, serta dalam pengambilan kebijakan terkait dengan dana dan program bantuan bagi masyarakat miskin. 


\section{Bab IV Metode Penelitian}

\section{A. Lokasi Penelitian}

Lokasi penelitian ditentukan secara sengaja (purposive) yaitu 5 (lima) jemaat di wilayah pelayanan Gereja Masehi Injili di Halmahera (GMIH) di Kabupaten Pulau Morotai (Kecamatan Morotai Selatan). Pemilihan lokasi tersebut didasarkan atas pertimbangan bahwa jemaat-jemaat tersebut merupakan jemaat pasca konflik dan masuk dalam Kategori C (lemah ekonomi dan finansial) oleh Sinode GMIH, serta sejumlah anggota jemaatnya yang tergolong miskin.

\section{B. Teknik Pengumpulan Data}

Jenis data yang akan dikumpulkan dalam penelitian ini terdiri dari data primer dan data sekunder. Data primer diperoleh melalui wawancara semi struktural, wawancara mendalam (in-depth interview) dengan responden, dan observasi lapangan. Selain itu, juga dilakukan diskusi kelompok terfokus (FGD) dengan diagram penyebab kemiskinan dari pendekatan Participatory Rural Appraisal (PRA). Data sekunder diperoleh melalui penelusuran berbagai kepustakaan dan dokumen, antara lain dari (1) instansi terkait (badan, dinas, kantor dalam lingkungan pemerintah provinsi, dan kabupaten/kota, (2) laporan hasil penelitian yang relevan, (3) biro pusat statistik, (4) dan berbagai informasi lainnya yang relevan dengan tujuan penelitian.

\section{Analisis Data}

Penelitian ini menggunakan pendekatan emik (emic approach) yang merupakan derivasi dari paradigma penelitian fenomenologi, naturalisme yang berusaha mengungkap fenomena berdasarkan apa yang diketahui, dipercayai, dirasakan dan dilakoni oleh anggota jemaat/masyarakat yang menjadi obyek penelitian. Data digambarkan melalui teknik deskripsi, baik dengan deskripsi interpretasi maupun deskripsi reproduksi. Analisis data dilakukan dengan teknik triangulasi (data, metodologi, dan teori) terhadap masalah kemiskinan dan faktor-faktor penyebabnya yang berkaitan dengan aset mata pencaharian berkelanjutan. 


\section{Bab V Hasil Yang Dicapai}

Hasil yang dicapai diuraikan sebagai berikut:

\section{A. Konsep Kemiskinan Menurut Jemaat/Masyarakat}

Berdasarkan hasil wawancara semi terstruktur dan focus group discussion (FGD) dengan jemaat/masyarakat miskin di lokasi penelitian, dapat dikemukakan bahwa konsep kemiskinan menurut mereka sebagian besar berbeda dengan apa yang dikemukakan pemerintah lewat Badan Pusat Statistik (BPS). Jemaat/masyarakat pada umumnya tidak merasakan bahwa mereka berada atau masuk dalam kategori miskin menurut pemerintah.

Sebagian besar jemaat/masyarakat menyatakan bahwa mereka tidak merasa miskin. Alasan mereka adalah bahwa keluarga yang masuk dalam kategori miskin adalah mereka yang tidak memiliki cukup makanan; tidak makan sehari 3 (tiga) kali; tidak memiliki rumah untuk berteduh (tinggal) atau mereka yang tinggal di kolong jembatan; mereka yang setiap harinya mengemis di jalan-jalan seperti yang mereka saksikan di tayangan-tayangan televisi. Pengeluaran atau belanja setiap hari jemaat/masyarakat hanya untuk memenuhi konsumsi makanan pokok seperti beras dan ikan. Jalan keluar mereka untuk menanggulangi persoalan makan sehari-hari adalah dengan hidup apa adanya, makan apa adanya, mengganti makanan pokok seperti beras dengan makanan hasil kebun lainnya seperti pisang, ubi kayu, dan sebagainya, serta terkadang berkunjung ke rumah keluarga yang lebih mampu di kota untuk meminjam uang maupun untuk kebutuhan lainnya.

Walaupun konsep kemiskinan jemaat/masyarakat terkesan mereka tidak berada di garis kemiskinan, namun berdasarkan hasil wawancara dan amatan terhadap kondisi jemaat/masyarakat di lokasi penelitian ini, sebagian besar pengeluarannya digunakan untuk memenuhi konsumsi makanan pokok yang sangat sederhana, biasanya tidak mampu atau mengalami kesulitan untuk berobat ke tenaga medis, kecuali Puskesmas atau yang disubsidi pemerintah, tidak mampu membeli pakaian satu kali dalam satu tahun untuk setiap anggota rumah tangga (biasanya hanya untuk anak-anak). Dari sisi kondisi fisik serta fasilitas tempat tinggal jemaat/masyarakat dinding rumahnya sebagian besar terbuat dari tembok dengan kondisi tidak baik/kualitas rendah, termasuk tembok yang yang tidak diplester, sebagian besar lantai rumah terbuat dari tanah/semen dengan kondisi tidak baik/kualitas rendah (lantai kasar), atap terbuat dari ijuk/rumbia/seng dengan kondisi tidak baik/kualitas rendah, penerangan bangunan tempat tinggal dari listrik yang sebagian besarnya memiliki 1 meteran untuk 2 rumah atau lebih, luas lantai rumah kecil (biasanya kurang dari $8 \mathrm{~m}^{2} / \mathrm{orang}$ ). 
Berdasarkan amatan peneliti, sumber air minum jemaat/masyarakat diambil dari sumber air tidak terlindung seperti sumur dan sungai. Sumur pada jemaat/masyarakat juga dipakai secara bersama antar beberapa keluarga yang tinggalnya berdekatan. Tempat buang air besar pada jemaat/masyarakat sebagian besar masih berupa jamban umum, bahkan ada yang bukan jamban atau langsung di pantai atau pinggiran sungai. Hal ini terlihat juga lewat laporan Badan Pusat Statistik (BPS) pada Bagian Sosial (Tabel 4.8) tentang Sumber Air Minum dan Sanitasi Sebagian Besar Warga di Kecamatan Morotai Selatan, 2015 (BPS Kabupaten Pulau Morotai, 2015). Selain itu, bahan bakar utama pada jemaat/masyarakat di lokasi penelitian masih menggunakan kayu bakar (bnd. BPS Kabupaten Pulau Morotai (Sarana dan Prasarana Tabel 6.4), 2015). Ketika dikonfirmasi mengenai hal ini kepada jemaat/masyarakat, jawaban yang diberikan adalah bahwa sumur yang dipakai digali secara bersama oleh keluarga-keluarga berdekatan yang kebetulan bersaudara, jadi wajar kalau dipakai bersama sebagai sesama saudara, sehingga tidak perlu dipersoalkan sebagai bagian dari persoalan kemiskinan. Mengenai tempat buang air besar di pantai atau d sekitar sungai, jemaat/masyarakat beranggapan bahwa hal itu masih wajar karena mereka tinggal di desa yang masih luas dan tidak mengganggu seperti halnya kalau hal itu dilakukan di kota. Selain itu, beberapa keluarga meganggap hal itu lebih cepat dan praktis ketimbang terkadang mengantri di jamban umum. Mengenai sumber energi bahan bakar utama dari kayu bakar, dikemukakan bahwa hal itu selain untuk melakukan penghematan sekaligus memanfaatkan ketersediaan bahan baku di seitar lokasi tempat tinggal mereka.

Tabungan atau simpanan uang di bank tidak dimiliki oleh jemaat/masyarakat. Dana yang dimiliki hanya bersumber dari jualan hasil kebun dan pekerjaan serabutan yang dilakukan (diversifikasi pekerjaan), seperti tenaga upahan untuk produksi kopra sejak naik pohon kelapa sampai pada proses pengasapan dan packing; melaut jika lautan di pesisir pasifik tidak bergelombang tinggi; dan sebagainya. Dana berupa uang tersebut habis untuk membiayai kehidupan sehari-hari seperti membeli beras, dan kebutuhan pokok lainnya, serta membiayai sekolah anak-anak. Hal ini juga yang melandasi konsep kemiskinan jemaat/masyarakat, yaitu pola pikir mereka yang merasa tidak berada dalam garis kemiskinan dikarenakan anak-anak dapat bersekolah walaupun hanya di tingkat dasar dan menengah. Kalaupun ada yang lulus dari perguruan tinggi, biasanya ada karena bantuan keluarga di kota atau karena bantuan pemerintah/swasta melalui beasiswa, dan hal tersebut sudah dianggap sebagai indikator mampu secara finansial atau tidak miskin.

\section{B. Faktor-Faktor Yang Mempengaruhi Perilaku Rumah Tangga Miskin}


1) Faktor Internal

a) Pemahaman Teologis

Agama yang di dalamnya pemahaman iman teologis umat/jemaat bertumbuh turut menyumbang bagi perilaku rumah tangga miskin, khususnya rumah tangga miskin yang beragama Kristen Protestan. Ajaran atau teks-teks kitab suci yang diajarkan/dikhotbahkan dari mimbar-mimbar gereja turut mempengaruhi jemaat/masyarakat kristen secara turun-temurun. Ada beberapa teks kitab suci yang muncul dalam wawancara yang dilakukan bersama jemaat/masyarakat di lokasi penelitian.

Salah satu teks suci yang sering muncul dalam wawancara adalah Injil Matius 5:3 yang berbunyi: "Berbahagialah orang miskin di hadapan Allah, karena merekalah yang empunya kerajaan Surga”. Secara tradisional, teks ini sering dipakai untuk "melegalkan" kemiskinan di kalangan umat kristiani. Maksudnya adalah untuk menghibur mereka yang miskin di dunia karena mereka akan kaya (selamat) di Surga. Selain itu teks ini jika ditelusuri secara akademis biasanya dipakai bangsa kolonial untuk menindas masyarakat pribumi secara struktural lewat agama yang dibawahnya ke Indonesia, agar tidak memberontak dalam kemiskinan mereka.

Jemaat/masyarakat di lokasi penelitian, khususnya yang rata-rata telah berusia lanjut sangat teguh berpegang pada teks ini, sehingga tidak melihat kemiskinan sebagai situasi yang harus dilawan, malahan dibiarkan secara turun-temurun dan cenderung menjadi tradisi kehidupan mereka. Faktor pemahaman teologis jemaat/masyarakat ini juga cenderung dikuatkan lewat tidak adanya programprogram pemberdayaan ekonomi yang digalakkan oleh gereja secara melembaga.

Selain teks di atas, ada juga teks kitab suci dari Mazmur 72:4,12-13 yang berbunyi: "Kiranya Ia memberikan keadilan kepada orang-orang yang tertindas dari bangsa itu, menolong orang-orang miskin, tetapi meremukan pemeraspemeras. Sebab Ia akan melepaskan orang yang berteriak minta tolong.., Ia akan sayang kepada orang lemah dan orang miskin.." Menurut mereka, walaupun mereka dikategorikan miskin, ditindas, namun Tuhan akan tetap membela dan tidak akan membiarkan mereka kelaparan. Keberpihakan Tuhan bagi mereka selalu nyata dan kongkrit, dimana mereka tidak pernah kelaparan walau dalam perang/konflik sekalipun. Hal ini terkait erat dengan pemahaman jemaat/masyarakat di lokasi penelitian yang terimbas konflik sosial beberapa tahun lalu, sehingga pemahaman ini turut menyumbang secara signifikan dalam perilaku hidup mereka.

b) Tingkat Pendidikan

Kabupaten Pulau Morotai merupakan kabupaten yang baru dimekarkan dari Kabupaten Halmahera Utara berdasarkan Undang-Undang Nomor 53 Tahun 2008. Kabupaten Halmahera Utara (berdiri pada 31 Mei 2003) merupakan bagian dari Provinsi Maluku Utara yang baru dimekarkan dari Provinsi Maluku pada tanggal 4 Oktober 1999, melalui UU RI Nomor 46 Tahun 1999. Hal mengenai pembentukan Kabupaten Pulau Morotai dikemukakan di sini dengan tujuan untuk menunjukan bahwa kabupaten ini masih berusia sangat muda sehingga semua 
proses pembangunan termasuk proses pembangunan pendidikan pun masih belum tersentuh dengan baik.

Letak Pulau Morotai yang jauh dari ibu kota pemerintahan Maluku di Ambon sebelum Maluku Utara dimekarkan dari Maluku dan Kabupaten Pulau Morotai dimekarkan dari Kabupaten Halmahera Utara, turut menyumbang bagi tertinggalnya proses pembangunan pendidikan di daerah ini. Salah satu hal penting di sini saat itu adalah sekolah-sekolah formal hanya berada di kota kabupaten, sedangkan di daerah pinggiran hanyalah sekolah yang diprakarsai masyarakat seperti sekolah kristen, itupun hanya pada tingkat pendidikan dasar dan lokasinya di daerah tertentu. Oleh karena itu, tidak mengherankan bahwa jemaat/masyarakat yang berusia di atas 50 tahun rata-rata hanya mengenyam pendidikan dasar bahkan ada yang tidak bersekolah secara formal.

Tingkat pendidikan tersebut mempengaruhi pandangan mereka terhadap konsep kemiskinan seperti telah diuraikan di atas, yang berdampak pada perilaku mereka yang lebih suka menikmati hidup apa adanya dan merasa nyaman dengan pola hidup yang telah dipraktekan secara turun temurun. Mereka merasa nyamannyaman saja terhadap situasi kemiskinan, dimana kerja di kebun atau pekerjaan serabutan lainnya dengan penghasilan yang hanya cukup untuk makan sehari-hari sudah cukup memberi kenyamanan hidup.

\section{2) Faktor Eksternal}

a) Dampak Konflik dan Pemerataan Bantuan Pemerintah

Salah satu faktor yang cukup mempengaruhi pemikiran dan perilaku jemaat/masyarakat miskin di lokasi penelitian adalah konflik masyarakat yang terjadi di Ambon-Maluku tahun 1999 yang merambat ke Maluku Utara termasuk ke Pulau Morotai. Menurut hasil wawancara dengan beberapa keluarga, terutama di Desa Daeo dan Sabatai Baru, ditemukan bahwa mereka dulunya memiliki rumah yang cukup layak dihuni, serta memiliki hewan ternak dan tanaman perkebunan (seperti cengkeh dan pala) yang banyak. Namun saat konflik terjadi, semuanya hilang karena mereka harus mengungsi ke luar dari desa tempat mereka tinggal dan ketika kembali, mereka memerlukan waktu yang lama untuk mengusahakan kembali tanaman dan hewan ternak serta rumah seperti yang dimiliki semula. Bahkan ada beberapa keluarga yang mengaku trauma untuk berusaha dan memiliki kembali hal-hal itu karena takut konflik kembali terjadi.

Hal lain yang ditemui adalah berkaitan dengan bantuan-bantuan pemerintah daerah khususnya Pemerintah Daerah Kabupaten Pulau Morotai seperti bantuan listrik masuk desa yang hanya mengutamakan kelompok-kelompok masyarakat tertentu dan tidak menjangkau masyarakat kelompok lainnya. Bantuan lain seperti bantuan bibit tanaman jangka panjang juga dikemukakan hanya menjangkau pengurus-pengurus kelompok tani tertentu dan tidak sampai ke masyarakat secara keseluruhan. Hal-hal ini membuat jemaat/masyarakat miskin menjadi apatis dan tidak lagi berusaha karena tertutupnya akses menuju sumber-sumber kebijakan di tingkat pemerintahan daerah. 
b) Ketersediaan Sumber Daya Alam

Meyangkut ketersediaan sumber daya alam, yang dimaksud di sini adalah jemaat/masyarakat miskin telah merasa cukup dengan tersedianya lahan untuk bertani/berkebun untuk mereka sebagai keluarga (baik keluarga orang tua maupun anak-anak muda yang baru menikah) untuk memenuhi kebutuhan keseharian walaupun jauh dari lokasi desa, sehingga mereka tidak terlalu mempedulikan lagi kegiatan-kegiatan dalam bidang sosial kemasyarakatan lainnya yang dapat meningkatkan taraf hidup mereka. Lautan juga menjadi sumber daya yang cukup memanjakan jemaat/masyarakat di sini karena dapat menjadi sumber penghasil ikan dan hasil lainnya setiap saat untuk kebutuhan keseharian mereka. Kegiatan ke kebun maupun ke laut yang dilakukan jemaat/masyarakat ini, merupakan kegiatan harian yang dilakukan dalam rangka memenuhi kebutuhan dasar makan-minum tanpa terorganisir dengan baik, sehingga kegiatan-kegiatan ini menjadi rutinitas yang tidak memperbaiki kualitas hidup keluarga dan jemaat/masyarakat secara umum yang berkaitan dengan keluarnya masyarakat dari garis kemiskinan.

\section{Bab VI Kesimpulan}

Kemiskinan dapat dilihat dari berbagai sudut pandang karena memiliki banyak sisi. Oleh karena itu sangat penting untuk mendefenisikan konsep kemiskinan bukan saja dari sisi kelompok kepentingan seperti pemerintah, tetapi juga dari sudut pandang masyarakat/jemaat miskin itu sendiri. Dalam penelitian ini, konsep kemiskinan yang muncul cenderung sangat subjektif yang mengindikasikan bahwa masyarakat/jemaat tidak merasa miskin seperti yang diliteraturkan oleh pemerintah dalam hal ini BPS. Hal ini sangat dipengaruhi oleh berbagai latar belakang yang berkembang dalam kehhidupan subjektif masyarakat/jemaat miskin di Morotai Selatan. Sangat diharapkan agar defenisi konsep kemiskinan yang diliteraturkan oleh pemerintah maupun kelompok lainnya dapat disinergikan dengan pemahaman masyarakat/jemaat agar dapat meghasilkan defenisi yang spesifik dan dinamis, sehingga berpengaruh pada kebijakan dan program penanggulangan pengentasan kemiskinan di daerah ini.

Selain konsep kemiskinan, perilaku masyarakat/jemaat miskin juga dipengaruhi oleh berbagai hal. Secara subjektif, perilaku masyarakat/jemaat miskin di lokasi penelitian dipengaruhi oleh faktor internal (pemahaman teologis jemaat dan tingkat pendidikan), dan faktor eksternal yaitu (dampak konflik sosial tahun 1999 dan pemerataan bantuan pemerintah serta ketersediaan sumber daya alam). Konsep kemiskinan dan perilaku masyarakat/jemaat miskin seperti dikemukakan di atas memerlukan perhatian serius pemerintah (daerah) dan lembaga agama (gereja) untuk ditindaklanjuti dalam diskusi-diskusi dan tindakan nyata selanjutnya, sebab kemiskinan hanya bisa diatasi dengan tindakan nyata bukan hanya dengan data dan teori-teori hasil penelitian. 


\section{Daftar Pustaka}

Badan Pendidikan dan Penelitian Kesejahteraan Sosial (BPPKS), 2012, Analisis Data Kemiskinan Berdasarkan Data Pendataan Program Perlindungan Sosial (PPLS) 2011, Jakarta: Kementerian Sosial RI bekerjasama dengan Badan Pusat Statistik (BPS).

Badan Pusat Statistik Kabupaten Pulau Morotai, 2015, Morotai Selatan Dalam Angka 2015, Moratai: BPS Kab. Pulau Morotai.

Nanuru, Ricardo F, 2011, Fungsi Sosial Gereja Menurut Konsep Rasionalitas Komunikatif Jürgen Habermas, Tesis, Yogyakarta: Fakultas Filsafat, Universitas Gadjah Mada.

Pattinama, Marcus J, 2009, Pengentasan Kemiskinan Dengan Kearifan Lokal (Studi Kasus di Pulau Buru - Maluku dan Surade - Jawa Barat), Makara, Sosial Humaniora, Vol. 13. No. 1, Juli 2009: 1-12.

Seldayo, H, et.al, 2003, Program Anti Kemiskinan di Indonesia. Pemetaan Informasi dan Kegiatan, Jakarta: Multystakeholders Forestry Programme (MFP) - Overseas Development Institute (ODI).

Smeru, 2003, Kebijakan Yang Memihak Pada Orang Miskin, (makalah), disampaikan pada Pelatihan Fasilitator dan Koordinator Regional Prakarsa Pembaruan Tata Pemerintahan Daerah Yogyakarta.

Taufiq Ahmad, et.al, 2010, Upaya Penanggulangan Kemiskinan Berbasis Pemberdayaan Masyarakat Lokal (Belajar dari Pelaksanaan Program Penanggulangan Kemiskinan Perkotaan di Kelurahan Bintoro, Kecamatan Demak, Kabupaten Demak), Politika, Jurnal Ilmu Politik, Volume I Nomor 1, April 2010. Hal. 7588.

Umanah, dkk., 2012, Pemetaan dan Strategi Pengembangan Pengentasan Kemiskinan Pada Desa-Desa Nelayan di Kabupaten Maluku Tenggara, Proposal Hibah Bersaing. 